\title{
MORPHOMETRIC AND MOLECULAR DIVERSITY AMONG THE ISOLATES OF COLLETOTRICHUM SPECIES CAUSING ANTHRACNOSE DISEASE OF CHILLI
}

\author{
Prathibha Veerappa Hanumanthappa ${ }^{1 *}$, Nanda Chinnaswamy ${ }^{2}$, Mohan Rao Annabathula ${ }^{3}$, \\ Ramesh SampangiramaReddy ${ }^{3}$, Nagaraja Niduvalli Ramachandrappa ${ }^{4}$
}

\footnotetext{
${ }^{1}$ ICAR-Central Plantation Crops Research Institute, Kasaragod, Kerala, India

${ }^{2}$ ICAR- Central Tobacco Research Institute, Research Station, Hunsur, Karnataka. India

${ }^{3}$ University of Agricultural Sciences, Bangalore, Karnataka. India

${ }^{4}$ ICAR-Central Plantation Crops Research Institute, Research Station, Karnataka. India
}

Received - October 31, 2017; Revision - December 15, 2017; Accepted - January 16, 2018

Available Online - February 20, 2018

DOI: http://dx.doi.org/10.18006/2018.6(1).124.130

\section{KEYWORDS \\ Chilli \\ Capsicum \\ Anthracnose \\ Colletotrichum \\ Fruit rot \\ AFLP}

\begin{abstract}
A total of sixty Colletotrichum isolates were purified from anthracnose disease samples, collected from 15 chilli growing districts of Karnataka. The isolates were evaluated for their morphological and genetic characterization using AFLP marker assay. Based on the morphological characterization, 40 isolates were identified as Colletotrichum capsici/truncatum and 20 as C. gloeosporioides. Considerable morphological variability was observed in $C$. gloeosporioides isolates compared to $C$. capsici isolates. AFLP marker assay could clearly differentiate the C. capsici and C. gloeosporioides isolates at $43 \%$ genetic similarity, thus complementing species classification based on morphological characterization. However, morphological and AFLP grouping of isolates indicates no clear correlation between clustering in the dendrogram and morphological grouping of C. capsici and C. gloeosporioides isolates this suggested existence of wide variability in both the species.
\end{abstract}

* Corresponding author

E-mail: prathibhavh_agri@yahoo.co.in (Prathibha Veerappa Hanumanthappa)

Peer review under responsibility of Journal of Experimental Biology and Agricultural Sciences.

Production and Hosting by Horizon Publisher India [HPI] (http://www.horizonpublisherindia.in/).

All rights reserved.
All the article published by Journal of Experimental Biology and Agricultural Sciences is licensed under a Creative Commons Attribution-NonCommercial 4.0 International License Based on a work at www.jebas.org.

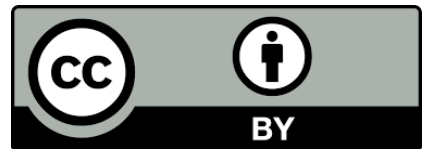




\section{Introduction}

Chilli (Capsicum annuum L.) is an important vegetable cum cash crop of Indian subcontinent. The crop is grown largely for its pungent fruits, which are used both green and ripe to impart pungency to the food. The sustainability in chilli production is threatened by many biotic stresses such as several insect pests and diseases (Isaac,1992). Among these, anthracnose disease caused by Colletotrichum species is a major constraint to chilli production in major chilli-growing regions of the world and often results in high yield losses (Than et al., 2008). This disease caused by a complex of Colletotrichum species, results in both pre and post-harvest fruit decay (Liu et al., 2016).The species of Colletotrichum associated with anthracnose disease includes Colletotrichum capsici, C. gloeosporioides, C. truncatum, C. dematium, C. acutatum, C. siamense, C. fructicola (Hong \& Hwang, 1998; Gopinath et al., 2006; Sharma \& Shenoy 2014), $C$. coccodes and C. karstii (Saini et al., 2016).

Colletotrichum infecting diverse hosts including cereals, legumes, vegetables, perennial crops and tree fruits have a high degree of pathogenic variability. Thus the accurate identification of the pathogen and species differentiation is imperative in development of appropriate management practices. Also studies on the variability of the pathogen populations are needed to direct breeding efforts towards long term resistance to anthracnose disease.
Classically, identification and characterization of Colletotrichum spp. was primarily relied on morphological characters such as colony color and growth rate, shape and size of conidia, optimal temperature for growth, presence or absence of setae and existence of the teleomorph (Adaskaveg \& Hartin, 1997; Freeman et al., 1998). Although these criteria are valuable but alone are not always adequate for reliable differentiation among Colletotrichum spp. due to variation in morphology and phenotype among species under environmental influences (Cannon et al., 2000).

To overcome the inadequacies of these traditional schemes, molecular techniques combined with morphological studies have proven to be effective for characterization of Colletotrichum species (Sreenivasaprasad \& Talhinhas, 2005; Van Hemelrijck et al., 2010). Therefore the present investigation was carried out to assess the variability in Colletotrichum spp. infecting chilli in Karnataka state of India using morphometric and molecular approaches

\section{Materials and Methods}

\subsection{Collection and isolation of Colletotrichum spp.}

Chilli fruits showing typical symptoms of anthracnose disease were collected from farmer's fields and chilli markets of 15 chilli growing districts of Karnataka, India (Table1). The pathogen was isolated by following standard tissue isolation method (Karuna-

Table 1 Colletotrichum spp. infecting chilli samples collected from 15 districts of Karnataka

\begin{tabular}{|c|c|c|}
\hline District & Colletotrichum spp. identified & Isolates \\
\hline Gulbarga & $\begin{array}{l}\text { C. capsici }(\mathrm{Cc}) \text {, } \\
\text { C. gleosporioides }(\mathrm{Cg})\end{array}$ & $\begin{array}{l}\text { Cc } 1 \\
\text { Cg } 1\end{array}$ \\
\hline Hassan & $\begin{array}{l}\text { C. capsici, } \\
\text { C. gleosporioides }\end{array}$ & $\begin{array}{l}\mathrm{Cc} 2 \\
\mathrm{Cg} 18\end{array}$ \\
\hline Bellary & C. capsici & $\mathrm{Cc} 3, \mathrm{Cc} 4, \mathrm{Cc} 40$ \\
\hline Hubli & C. capsici & Cc $5, \operatorname{Cc} 6, \operatorname{Cc} 7$ \\
\hline Gadag & $\begin{array}{l}\text { C. capsici, } \\
\text { C. gleosporioides }\end{array}$ & $\begin{array}{l}\text { Cc } 8, \text { Cc 9, Cc 10, Cc } 11 \\
\operatorname{Cg} 2\end{array}$ \\
\hline Haveri & C. capsici & Cc 12, Cc 13, Cc 14, Cc 15, Cc 16, Cc 17, Cc 18, Cc 19 \\
\hline Dharwad & $\begin{array}{l}\text { C. capsici, } \\
\text { C. gleosporioides }\end{array}$ & $\begin{array}{l}\text { Cc } 20, \mathrm{Cc} 21, \mathrm{Cc} 22, \mathrm{Cc} 23, \mathrm{Cc} 24, \mathrm{Cc} 30, \mathrm{Cc} 31 \\
\mathrm{Cg} 3, \mathrm{Cg} 4, \mathrm{Cg} 5, \mathrm{Cg} 6, \mathrm{Cg} 7, \mathrm{Cg} 8, \mathrm{Cg} 9\end{array}$ \\
\hline Chitradurga & C. capsici & Cc 25, Cc 26, Cc 27, Cc 28 \\
\hline Tumkur & C. capsici & Cc 29 \\
\hline Raichur & $\begin{array}{l}\text { C. capsici, } \\
\text { C. gleosporioides }\end{array}$ & $\begin{array}{l}\text { Cc } 32 \\
\text { Cg } 10\end{array}$ \\
\hline Bijapur & C. capsici & $\mathrm{Cc} 33, \mathrm{Cc} 34$ \\
\hline Davanagere & C. capsici & $\mathrm{Cc} 35, \mathrm{Cc} 36$ \\
\hline Chikkamaglur & $\begin{array}{l}\text { C. capsici, } \\
\text { C. gleosporioides }\end{array}$ & $\begin{array}{l}\text { Cc } 37 \\
\mathrm{Cg} 14, \mathrm{Cg} 15, \mathrm{Cg} 16\end{array}$ \\
\hline Bangalore & $\begin{array}{l}\text { C. capsici, } \\
\text { C.gleosporioides }\end{array}$ & $\begin{array}{l}\text { Cc } 38, \text { Cc } 39 \\
\operatorname{Cg~} 17\end{array}$ \\
\hline Belgaum & C. gleosporioides & $\mathrm{Cg} \mathrm{11,} \mathrm{Cg} \mathrm{12,} \mathrm{Cg} 13$ \\
\hline Kolar & C. gleosporioides & $\mathrm{Cg} 19, \mathrm{Cg} 20$ \\
\hline
\end{tabular}

Journal of Experimental Biology and Agriculture Science http://www.jebas.org 
vishunavat \& Kolte, 1998). The pathogen was purified using single spore isolation technique (Karuna-vishunavat \& Kolte, 1998). The pathogenicity of monoconidial cultures of all the isolates was conducted by inoculating on hybrid NS1701 by following detached fruit method (AVRDC, 2003).

\subsection{Morphological variability}

Morphological variability viz., colony characteristics (colony colour, texture, margin and radial growth) and conidial morphology of 60 isolates of Colletotrichum spp. was assessed on Potato Dextrose Agar (PDA) medium. Petri dishes containing 15 $\mathrm{ml}$ of PDA medium was inoculated centrally with $5 \mathrm{~mm}$ diameter mycelial disc taken from the periphery of 5 days old culture. Three replications were maintained for each isolate and the plates were incubated at $25 \pm 1^{\circ} \mathrm{C}$. Conidial size, shape and acervuli size of 60 isolates were recorded using Leica bright field microscope. The colony morphology was recorded by following mycological chart (Rayner, 1970).

\subsection{Molecular variability}

Amplified Fragment Length Polymorphism (AFLP) molecular marker assay was used to study the variability among sixty isolates of Colletotrichum spp. of Karnataka. Two isolates each of C. capsici and C. gloeosporioides sampled from Andhra Pradesh which were earlier characterized for their virulence pattern were also included in the study (Nanda, 2011).

\subsection{Isolation of DNA and PCR amplification}

The DNA was extracted from five days old mycelia grown on Potato dextrose broth by following procedure of Sharma et al. (2005) with minor modifications. AFLP protocol outlined by Vos et al. (1995) was followed with minor modifications in some steps. A total of nine, three nucleotide selective primer combinations were used for the study of genetic diversity in 60isolates of Colletotrichum spp. The primers were first screened using DNA and the combinations that showed good amplification were selected for final amplifications.

Genomic DNA was digested with 4 units of $\mathrm{MseI}$ and 10 units of EcoRI restriction endonucleases at $37^{\circ} \mathrm{C}$ for 3 hours in a PCR machine. The digested product was loaded on to 1.2 per cent agarose gel to confirm the complete digestion of the genomic DNA. The digested DNA was ligated with MseI and Eco-R I adapters with T4 DNA ligase. Ligation reaction mix was incubated at $37^{\circ} \mathrm{C}$ for overnight. The digested / ligated product was diluted to $1: 10$ with $\mathrm{T}_{10} \mathrm{E}_{1}(\mathrm{pH} 8)$ and stored at $-20^{\circ} \mathrm{C}$.

An initial round of PCR (Pre-amplification) was carried to enrich a subset of the AFLP template; the primers used in pre-amplification have a single base selection. In the
Pre-amplification reaction, a $3.0 \mu \mathrm{l}$ diluted ligation product, $2 \mu \mathrm{l}$ each of MseI and EcoRI, $2 \mu \mathrm{l}$ dNTPs, $1 \mu 1$ 10X PCR buffer were mixed in 1.0 unit of Taq polymerase and used in total volume of $10.2 \mu 1$. Pre-amplification was performed with an amplification profile of $94^{\circ} \mathrm{c}$ for $30 \mathrm{~s}$, annealing at $56^{\circ} \mathrm{c}$ for $1 \mathrm{~min}$, extension at $72^{\circ} \mathrm{c}$ for $1 \mathrm{~min}$, repeated for $20 \mathrm{cycles}$ and then at $10^{\circ} \mathrm{c}$ for $30 \mathrm{~min}$. The pre-amplified product was loaded on to $1.2 \%$ agarose gel to check the amplification. Depending on the amplification intensity, the amplified product was diluted to1:3 in TE buffer and used as template for re-amplification using AFLP primers, each containing three-selective nucleotides. Re-amplification PCR was performed in $10.2 \mu \mathrm{l}$ reactions containing of $3.0 \mu \mathrm{l}$ template DNA, $2.0 \mu \mathrm{l}$ each of EcoRI and MseI selective nucleotide primer, $2.0 \mu \mathrm{l}$ dNTPs, $1 \mu 1$ 10X PCR buffer and 1.0 unit of Taq polymerase. The re-amplification reaction was carried out with cycling parameters of $94^{\circ} \mathrm{C}$ for $30 \mathrm{~s}, 65^{\circ} \mathrm{c}$ for $30 \mathrm{~s}$ reducing by $0.7^{\circ} \mathrm{C} /$ cycle to $56^{\circ} \mathrm{C}$, $72^{\circ} \mathrm{C}$ for $1 \mathrm{~min}$ for 11 cycles, and $94^{\circ} \mathrm{C}$ for $30 \mathrm{~s}, 56^{\circ} \mathrm{C}$ for $30 \mathrm{~s}$ and $72^{\circ} \mathrm{C}$ for $1 \mathrm{~min}$ for 24 cycles followed by $10^{\circ} \mathrm{C}$ for 30 minutes.

PCR were carried out separately for each primer pair and the products were denatured immediately by adding eight microlitres of stop loading dye to each sample. Denaturation was carried out at $94^{\circ} \mathrm{C}$ for $5 \mathrm{~min}$ and then cooled to $10^{\circ} \mathrm{C}$ for $5 \mathrm{~min}$. Electrophoresis of the samples was carried out on $6 \%$ polyacrylamide gels, by loading $3 \mu 1$ of each final PCR product. Electrophoresis was carried out at 1,200 V for 3.0h until the dark blue dye ran off. The gels were then seperated and developed silver staining technique.

\subsection{Analysis of AFLP profiles}

The amplicons generated in AFLP, behave as dominant markers. Therefore, the score ' 1 ' was assigned for the presence of band and ' 0 ' for absence of band at each loci. The variation in band intensity is not taken into consideration to avoid confusion in scoring. The binary data was used to estimate pair wise genetic distance based on Jaccard's coefficients using NTSYS-pc version 2.0 software. Dendrogram was constructed using Unweighted Paired Group Arithmetic Mean (UPGMA) algorithm based on distance matrix.

\section{Results and Discussion}

In total sixty isolates of Colletotrichum species were purified after isolation from infected chilli fruits collected from 15 chilli growing districts of Karnataka (Table1). Among the sixty collected isolates 40 fitted the description of C. capsici/truncatum and twenty fitted the description of $C$. gloeosporioides (Table 6). All the 60 isolates of Colletotrichum produced typical anthracnose symptoms such as sunken circular spots on fruit surface on $3^{\text {rd }}$ day after inoculation. 
Table 2 Colony growth rate of Colletotrichum capsici $(\mathrm{Cc})$ isolates on Potato dextrose agar (PDA) and Chilli

fruit extract agar (CFEA) media

\begin{tabular}{|c|c|c|c|}
\hline \multirow{2}{*}{ Sl. No. } & \multirow{2}{*}{ Isolate No. } & \multicolumn{2}{|c|}{ Colony diameter (mm) } \\
\hline & & PDA & CFEA \\
\hline 1 & Cc 1 & 67 & 75 \\
\hline 2 & Cc 2 & 70 & 80 \\
\hline 3 & Cc 3 & 70 & 74 \\
\hline 4 & Cc 4 & 68 & 72 \\
\hline 5 & Cc 5 & 71 & 75 \\
\hline 6 & Cc 6 & 70 & 83 \\
\hline 7 & Cc 7 & 71 & 87 \\
\hline 8 & Cc 8 & 70 & 79 \\
\hline 9 & Cc 9 & 72 & 80 \\
\hline 10 & Cc 10 & 69 & 75 \\
\hline 11 & Cc 11 & 70 & 76 \\
\hline 12 & Cc 12 & 68 & 90 \\
\hline 13 & Cc 13 & 67 & 86 \\
\hline 14 & Cc 14 & 64 & 80 \\
\hline 15 & Cc 15 & 69 & 82 \\
\hline 16 & Cc 16 & 70 & 80 \\
\hline 17 & Cc 17 & 73 & 78 \\
\hline 18 & Cc 18 & 72 & 88 \\
\hline 19 & Cc 19 & 62 & 81 \\
\hline 20 & Cc 20 & 65 & 78 \\
\hline 21 & Cc 21 & 70 & 89 \\
\hline 22 & Cc 22 & 62 & 84 \\
\hline 23 & Cc 23 & 61 & 83 \\
\hline 24 & Cc 24 & 68 & 82 \\
\hline 25 & Cc 25 & 69 & 80 \\
\hline 26 & Cc 26 & 65 & 80 \\
\hline 27 & Cc 27 & 62 & 74 \\
\hline 28 & Cc 28 & 64 & 83 \\
\hline 29 & Cc 29 & 68 & 84 \\
\hline 30 & Cc 30 & 65 & 80 \\
\hline 31 & Cc 31 & 69 & 81 \\
\hline 32 & Cc 32 & 64 & 73 \\
\hline 33 & Cc 33 & 65 & 80 \\
\hline 34 & Cc 34 & 64 & 84 \\
\hline 35 & Cc 35 & 62 & 83 \\
\hline 36 & Cc 36 & 60 & 82 \\
\hline 37 & Cc 37 & 65 & 74 \\
\hline 38 & Cc 38 & 64 & 75 \\
\hline 39 & Cc 39 & 68 & 72 \\
\hline 40 & Cc 40 & 70 & 74 \\
\hline $\mathrm{CD} @ 1$ & & & \\
\hline
\end{tabular}

\subsection{Morphological variability}

The colony growth rate of both $C$. capsici and $C$. gloeosporioides isolates varied and results of study revealed that isolates of $C$. gloeosporioides grew faster than C. capsici isolates (Table $2 \& 3$ ). All 40 C. capsici isolates were produced whitish grey colony with irregular margin and flat texture. However, twenty $C$. gloeosporioides isolates were categorized into three morphological groups (CgI, $\mathrm{CgII}, \mathrm{CgIII})$. $\mathrm{CgI}$ produced white colony with circular margin and fluffy textured while CgII and CgIII formed whitish grey colony with fluffy textured but differed in colony margin (Table $4 \& 5$ ).

Earlier researchers also reported such morphological variations among Colletotrichum spp. Sharma et al. (2005) categorized 37 isolates of $C$. capsici into five morphological groups based on variation in morphological traits. Than et al. (2008) differentiated isolates of chilli anthracnose from Thailand into three species, viz., C. capsici, C. accutatum and C. gloeosporioides. Similarly, Thind \& Jhooty (1985) categorized 150 isolates of C. capsici and C. gloeosporioides causing anthracnose of chilli into eight groups on the basis of colony diameter and number of acervuli.

Table 3 Colony growth rate of $C$. gloeosporioides $(\mathrm{Cg})$ isolates on Potato dextrose agar (PDA) and Chilli fruit extract agar (CFEA) media

\begin{tabular}{|c|c|c|c|}
\hline \multirow{2}{*}{ S1. No. } & \multirow{2}{*}{ Isolate No. } & \multicolumn{2}{|c|}{ Colony diameter $(\mathrm{mm})$} \\
\hline & & PDA & CFEA \\
\hline 1 & $\operatorname{Cg} 1$ & 78 & 90 \\
\hline 2 & $\mathrm{Cg} 2$ & 76 & 78 \\
\hline 3 & $\operatorname{Cg} 3$ & 80 & 90 \\
\hline 4 & $\mathrm{Cg} 4$ & 89 & 89 \\
\hline 5 & $\mathrm{Cg} 5$ & 90 & 90 \\
\hline 6 & $\mathrm{Cg} 6$ & 90 & 90 \\
\hline 7 & $\mathrm{Cg} 7$ & 89 & 90 \\
\hline 8 & $\mathrm{Cg} 8$ & 90 & 88 \\
\hline 9 & $\mathrm{Cg} 9$ & 90 & 89 \\
\hline 10 & $\mathrm{Cg} 10$ & 85 & 90 \\
\hline 11 & $\mathrm{Cg} 11$ & 90 & 90 \\
\hline 12 & $\mathrm{Cg} 12$ & 88 & 90 \\
\hline 13 & $\mathrm{Cg} 13$ & 82 & 90 \\
\hline 14 & $\mathrm{Cg} 14$ & 83 & 90 \\
\hline 15 & Cg 15 & 85 & 90 \\
\hline 16 & $\mathrm{Cg} 16$ & 90 & 90 \\
\hline 17 & Cg 17 & 78 & 90 \\
\hline 18 & $\mathrm{Cg} 18$ & 88 & 90 \\
\hline 19 & Cg 19 & 80 & 74 \\
\hline 20 & $\mathrm{Cg} 20$ & 79 & 85 \\
\hline CD @ & & & \\
\hline
\end{tabular}


Table 4 Colony characters of $C$. capsici and C. gloeosporioides isolates on Potato dextrose agar (PDA) medium

\begin{tabular}{|c|c|c|c|c|}
\hline \multirow{2}{*}{ Group } & \multirow{2}{*}{ C. capsici (Cc) and C. gloeosporioides ( $\mathrm{Cg}$ ) isolates } & \multicolumn{3}{|c|}{ Colony characters } \\
\hline & & Colour & Texture & Margin \\
\hline $\mathrm{CcI}$ & $\mathrm{Cc} 1$ to $\mathrm{Cc} 40$ & Whitish gray & Flat & Irregular \\
\hline $\mathrm{Cg} \mathrm{I}$ & $\mathrm{Cg} 1, \mathrm{Cg} 2, \mathrm{Cg} 3, \mathrm{Cg}$ 9, $\mathrm{Cg} 13, \mathrm{Cg} 14, \mathrm{Cg} 17, \mathrm{Cg} 19, \mathrm{Cg} 20$ & White & Fluffy & Circular \\
\hline $\mathrm{Cg}$ II & $\mathrm{Cg} 4, \mathrm{Cg} 7, \mathrm{Cg} 10, \mathrm{Cg} 12, \mathrm{Cg} 18$ & Whitish gray & Fluffy & Irregular \\
\hline Cg III & $\operatorname{Cg} 5, \operatorname{Cg} 6, \operatorname{Cg} 8, \operatorname{Cg~} 11, \operatorname{Cg} 15, \mathrm{Cg} 16$ & Whitish gray & Fluffy & Circular \\
\hline
\end{tabular}

Table 5 Colony characters of $C$. capsici and $C$. gloeosporioides isolates on Chilli fruit extract agar (CFEA) medium

\begin{tabular}{|c|c|c|c|c|}
\hline \multirow{2}{*}{ Group } & \multirow{2}{*}{ C. capsici (Cc) and C. gloeosporioides (Cg) isolates } & \multicolumn{3}{|c|}{ Colony characters } \\
\hline & & Colour & Texture & Margin \\
\hline $\mathrm{Cc} \mathrm{I}$ & $\mathrm{Cc} 1$ to $\mathrm{Cc} 40$ & Grayish Black & Flat & Irregular \\
\hline $\mathrm{Cg} \mathrm{I}$ & $\begin{array}{l}\mathrm{Cg} 6, \mathrm{Cg} 7, \mathrm{Cg} 8, \mathrm{Cg} \mathrm{9,Cg} \mathrm{10,} \mathrm{Cg} \mathrm{11,} \mathrm{Cg} \mathrm{12,} \mathrm{Cg} \mathrm{13,} \mathrm{Cg} \mathrm{14,} \mathrm{Cg} \mathrm{15,} \\
\mathrm{Cg} 16, \mathrm{Cg} 17, \mathrm{Cg} 18\end{array}$ & Grayish olive green & Fluffy & Circular \\
\hline $\mathrm{Cg}$ II & $\mathrm{Cg} \mathrm{1,Cg} \mathrm{2,} \mathrm{Cg} \mathrm{3,} \mathrm{Cg} \mathrm{4,} \mathrm{Cg} \mathrm{5,} \mathrm{Cg} 19$ & Whitish gray & Fluffy & Circular \\
\hline
\end{tabular}

Table 6 Characters of Acervuli and conidia produced by C. capsici and C. gloeosporioides isolates on Potato dextrose agar (PDA) medium

\begin{tabular}{|cccc|}
\hline Colletotrichum isolates & Conidia shape & Conidia size $(\mu \mathrm{m})$ & Acervulli size $(\mu \mathrm{m})$ \\
\hline $\begin{array}{c}\text { C. } \text { capsici } \\
(\text { Cc } 1 \text { to Cc 40) }\end{array}$ & Falcate with acute apex & $21.4-25.0$ x 3.8 -4.3 & $149.03-165.34$ \\
\hline $\begin{array}{c}\text { C. gloeosporioides } \\
\text { (Cg } 1 \text { to Cg 20) }\end{array}$ & Cylindrical with obtuse end & $10.8-12.1 \times 3.1-3.9$ & $135.20-154.21$ \\
\hline
\end{tabular}

According to Jameel-Akhtar et al., (2008), reported that $C$. capsici produced falcate fusiform conidia with narrow truncated acute apices. They were normally one-celled, hyaline and uni-nucleate while, Prasanna Kumar (2001) reported that C. gloeosporioides produce hyaline, unicellular and either cylindrical with obtuse ends or elliptical conidia with a rounded apex or narrow truncate base conidia.

In the current study higher morphological variability was observed in C.gloeosporioides isolates on both tested media as compared to $C$. capsici isolates. These findings are similar to previous report, higher variability was observed within the $C$. gloeosporioides populations where the genetic heterogeneity may be explained by the presence of a perfect stage (Freeman et al.,1998).

\subsection{Molecular variability}

A total of 180 AFLP loci were sampled using nine primer combinations and all the primers were highly efficient in detecting polymorphism to an extent of $100 \%$. Highest number of loci was sampled with the primer combination 5 (E+AAG, M+GCC). Clustering of Colletotrichum spp. isolates based on Jaccard's dissimilarity co-efficient and UPGMA algorithm could clearly differentiate the two species of Colletotrichum at 43 per cent genetic similarity (Figure 1). In the cluster consisting of $40 \mathrm{Cc}$ isolates, the isolates were sub grouped under 5 main clusters, 8 subclusters and 4 solitary clusters. Twenty $\mathrm{Cg}$ isolates were grouped under second subgroup with 3 main clusters, 5 subclusters and 2 solitary clusters.

Highly virulent $C$. capsici isolate, Cc 40 (sampled from Bellary district) formed a solitary cluster and highly virulent $\mathrm{Cg}$ isolate sampled from Dharwad district and $\mathrm{Cg}$ isolates sampled from Belgaum grouped into single cluster. Highly virulent $C$. gloeosporioides isolate of Andhra Pradesh formed a solitary cluster. The clustering in the dendrogram was not clearly correlated with geographical distribution and morphological characterization.

Considering that morphological character based assay alone is not always adequate for species identification due to overlap in morphological characters between species (as they evolve under different natural pressure) (Adaskaveg \& Hartin, 1997). Application of both molecular diagnostic tools and morphological traits is an appropriate option for studying Colletotrichum species 


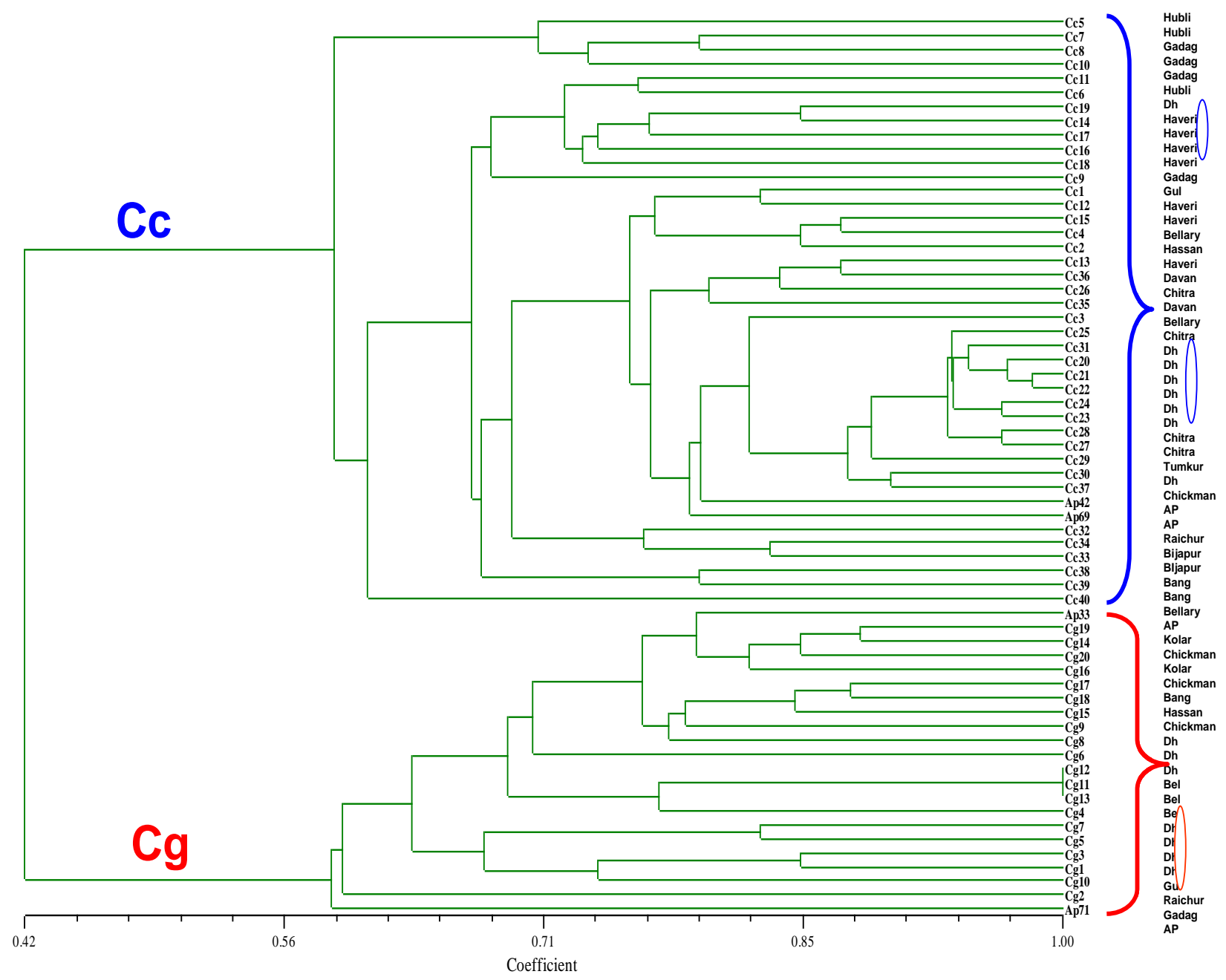

Figure 1 AFLP marker data-based dendrogram depicting grouping of Colletotrichum spp. isolates

complexes (Cannon et al., 2000). Thus, in the present study DNAbased assay using AFLP marker system was used along with morphological traits to confirm species identity of the Colletotrichum isolates.

Similarly Than et al. (2008) characterized three Colletotrichum spp viz., C. acutatum, C. capsici and C. gloeosporioides associated with anthracnose disease based on morphological characterization and by sequencing ITS region and beta tubulin gene and pathogenicity. Ratanacherdchai et al. (2010) analyzed the genetic diversity among isolates of $C$. gloeosporioides and $C$. capsici from Thailand by Inter simple sequence repeat (ISSR) analysis and reported that there were two distinct groups of $C$. gloeosporioides and C. capsici.

Morphological and AFLP based assays could clearly differentiate the 60 isolates of Colletotrichum spp. into two species viz., $C$. capsici and C. gloeosporioides. Considerable inter and intraspecific variability was observed among the isolates of both $C$. capsici and $C$. gloeosporioides. The accurate taxonomic identification of the pathogen and their variability plays a major role in disease dynamics and consequently in the disease management strategies. Use of resistant cultivars is an economical and eco-friendly option for effective management of the disease. However, management of disease through breeding of pathogen-resistant cultivars has only had limited success due to frequent breakdown of resistance under field conditions because of higher variability, pathogen may adopt faster to fluctuating environment. Thus the variability among the isolates of $C$. capsici and C. gloeosporioides should be considered when these two species are used for screening of chilli genotypes for anthracnose resistance. 


\section{Conflict of interest}

Authors would hereby like to declare that there is no conflict of interests that could possibly arise.

\section{References}

Adaskaveg JE, Hartin RJ (1997) Characterization of Colletotrichum acutatum isolates causing anthracnose of almond and peach in California. Journal of Plant Pathology 7: 979-987.

Asian Vegetable Research and Development Centre (2003) AVRDC progress report for 2002. Asian Vegetable Research and Development Centre, Taiwan, China.

Cannon PF, Bridge PD, Monte E (2000) Linking the past, present, and future of Colletotrichum systematics. APS Press, Pp1-20.

Freeman ST, Katan E, Shabi (1998) Characterization of Colletotrichum species responsible for anthracnose diseases of various fruits. Plant Disease 82: 596-605.

Gopinath KN, Radhakrishnan V, Jayaral J (2006) Effect of propiconazole and difenoconazole on the control of anthracnose of chili fruit caused by Colletotrichum capsici. Crop Protection 25: 1024-1031.

Hong JK, Hwang BK (1998) Influence of inoculum density wetness duration, plant age, inoculation method and cultivar resistance on infection of pepper plants by Colletotrichum cocodes. Plant Disease 82: 1079 - 1083.

Isaac S (1992) Fungal Plant Interaction. London: Chapman and Hall Press Pp-115.

Jameel-Akhtar, Singh MK, Chaube HS (2008) Effect of nutrition on formation of acervuli, setae and sporulation of the isolates of Colletotrichum capsici. Pantnagar Journal of Research $6: 110-113$

Karuna-vishunavat, Kolte SJ (1998) Essentials of phytopathological techniques. Kalyani publication, New Delhi, Pp-217.

Liu F, Tang G, Zheng X, Li Y, Sun X, Qi X, Zhou Y (2016) Molecular and phenotypic characterization of Colletotrichum species associated with anthracnose disease in peppers from Sichuan Province, China. Scientific reports 6:1-16.

Nanda C (2011) Dynamics of anthracnose disease causing pathogen, inheritance and SSR marker-assisted tagging of resistance to anthracnose in chilli (Capsicum spp.). $\mathrm{PhD}$ Thesis submitted to the University Agricultural Sciences, Bangalore.

Prasanna Kumar MK (2001) Management of post harvest diseases of Mango (Mangifera indica L.) M. Sc.(Agri.) Thesis submitted to the University Agricultural Sciences, Dharwad Pp-175.

Ratanacherdchai KHK, Wang, Lin FC, Soytong K (2010) ISSR for comparison of cross-inoculation potential of Colletotrichum capsici causing chilli anthracnose. African journal of Microbiology Research 4:76-83.

Rayner RW (1970) A mycological colour chart. Common wealth Mycological Institute, Kew, UK.

Saini TJ, Gupta SG, Char BR, Zehr UB, Anandalakshmi R (2016) First report of chilli anthracnose caused by Colletotrichum karstii in India. New Disease Report 34:6.

Sharma G, Shenoy BD (2014) Colletotrichum fructicola and C. siamense are involved in chilli anthracnose in India. Archives of Phytopathology and Plant Protection 47:1179-1194.

Sharma PN, Kaur M, Sharma OP, Sharma P, Pathania A (2005) Morphological, pathogical and molecular variability in Colletotrichum capsici the cause of fruit rot of hot pepper in the subtropical region of North-western. Indian Journal of Phytopathology 153: 232-237.

Sreenivasaprasad S, Talhinhas P (2005) Genotypic and phenotypic diversity in Colletotrichum acutatum, a cosmopolitan pathogen causing anthracnose on a wide range of hosts. Molecular Plant Pathology 6:361-378.

Than PP, Jeewon R, Hyde KD, Pongsupasamit S, Mongkolporn Taylor PWJ (2008) Characterization and pathogenicity of Colletotrichum species associated with anthracnose on hot pepper (Capsicum spp.) in Thailand. Plant Pathology 57: 562-572.

Thind TS, Jhooty JS (1985) Relative prevalence of fungal diseases of hot pepper fruits in Punjab. Indian Journal of Mycology and Plant Pathology 15: 305-307.

Van Hemelrijck W, Debode J, Heungens K, Maes M, Creemers P (2010) Phenotypic and genetic characterization of Colletotrichum isolates from Belgian strawberry fields. Plant Pathology 59:853-861

Vos PR, Hogers M, Bleeker M, Reijans T, Van de lee M, Hoemes A, Frijters J, Peleman M, Kuiper M (1995) AFLP: A new technique for DNA fingerprinting. Nucleic Acids Research 23: 4407-4414. 